\title{
Pelvis metastazları
}

\section{Metastases of the pelvis}

\author{
Bülent Erol ${ }^{1}$, Bahattin Kerem Aydın² \\ ${ }^{1}$ Marmara Üniversitesi Tıp Fakültesi, Ortopedi ve Travmatoloji Anabilim Dalı, Maltepe, İstanbul \\ ${ }^{2}$ Selçuk Üniversitesi Tıp Fakültesi Ortopedi ve Travmatoloji Anabilim Dalı, Selçuklu, Konya
}

Kemik doku, akciğer ve karaciğerden sonra en sık metastaz alan üçüncü dokudur. Pelvis ise vertebral kolondan sonra en sık metastatik kemik lezyonların izlendiği bölgedir. Bu bölge lezyonlarının tedavisinde amaç hastanın ağrısının azaltılması, hareket kısıtlılığının giderilmesi ve alt ekstremite fonksiyonlarının sağlanmasıdır. Bu lezyonların tedavisinde ortopedik cerrah, medikal onkolog, radyasyon onkoloğu ve girişimsel radyologdan oluşan bir multidisipliner ekip tarafindan, hastanın genel durumu da göz önüne alınarak, karar verilmelidir. Hastaların tedavilerinde, radyoterapi gibi cerrahi dışı işlemler; radyofrekans ablasyon, kriyoablasyon, perkütan çimento uygulamaları gibi minimal invaziv işlemler; küretaj, çimentolama, rezeksiyon, çeşitli artroplasti uygulamaları, hemipelvektomileri içeren birçok cerrahi yöntem kullanılabilir. Bu derleme makalede, pelvis metastatik lezyonlarının yönetiminde kullanılan güncel sınıflamalar ve tedavi yöntemlerinin sunulması amaçlanmıştır. Hastaların genel durumları, primer hastalığın neoadjuvan tedavilere yanıtı, beklenen yaşam süreleri, lezyonların yeri ve sayısı tedavi planlamasında önemlidir. Bu derleme makalesinde bahsedilen sınıflama sistemleri kullanılarak kısıtlı sağkalıma sahip hastaların tedavilerinin planlanmasında aşırı veya gereksiz tedavi düzenlemelerinin önlenmesi sağlanabilir.

Anahtar sözcükler: pelvis; kemik; metastaz; tedavi
Bone tissue is the third most common tissue for metastasis after lung and liver. Pelvis is the most common site of metastatic bone after vertebral column. The aim of treatment of lesions in these locations is to reduce the pain of the patient, to overcome immobility, and provide lower extremity functions. In the treatment of these lesions, a multidisciplinary team consisting of an orthopedic surgeon, a medical oncologist, a radiation oncologist, and an interventional radiologist should be formed, taking into account the general condition of the patient. Many surgical methods including curettage, cementation, resection, various arthroplasty applications and hemipelvectomies; non-surgical procedures such as radiotherapy; minimally invasive procedures such as radiofrequency ablation, cryoablation, percutaneous cement applications are available. In this review article, we aimed to present the current classifications and treatment methods used in the management of pelvic metastatic lesions. The general condition of the patient, response of the primary disease to neoadjuvant therapies, expected survival times, number and location of lesions; all are important in treatment planning. It is possible to prevent under or over treatment arrangements in the treatment planning of patients with limited life expectancies by using the classification systems mentioned in this review.

Key words: pelvis; bone; metastasis; treatment
P elvis bölgesindeki kemik metastazları, şiddetli ağrı ve hareket kısıtlılığına yol açabilmeleri nedeniyle, hastaların hayat kalitesini olumsuz yönde etkileyebilmektedir. Çoğu lezyon, cerrahi gereksinim duyulmadan ağrı azaltılması ve radyoterapi ile yönetilebilirken, bir kısım lezyonlar için cerrahi kaçınılmazdır. ${ }^{[1]}$ Pelvisin karmaşık anatomisi ve hayati yapılara yakın komşuluğu nedeniyle, bu bölge cerrahisi ekstremite metastazlarına göre daha zordur.
Akciğer ve karaciğerden sonra, en sık metastatik lezyonların izlendiği doku kemiktir. Pelvis ise vertebral kolondan sonra kemik metastazlarının en sık izlendiği bölgedir. En sık akciğer, meme, prostat, tiroid ve renal hücreli tümörlerin metastatik lezyonları bu bölgede görülür. ${ }^{[2]}$

Metastatik pelvis lezyonu bulunan birçok hastada tam şifa sağlamak mümkün değildir. Tedavinin amaCı hayat kalitesini artırarak palyasyon sağlamaktır.

- İletişim adresi: Doç. Dr. Bahattin Kerem Aydın, Selçuk Üniversitesi Tıp Fakültesi, Ortopedi ve Travmatoloji Anabilim Dalı, Alaeddin Keykubat Kampüsü, 42100 Selçuklu, Konya Tel: 0332 - 2445010 e-posta: bkaydin@yahoo.com

- Geliș tarihi: 12 Eylül $2019 \quad$ Kabul tarihi: 22 Ekim 2019 
Cerrahi müdahaleler ile; ağrı kontrolünün sağlanması, patolojik kırık veya kırık olasılığı olan bölgelerin stabilizasyonu ve bazen de lezyonların rezeksiyonu amaçlanır.

Son yıllarda kemoterapi, radyoterapi, hormonal ve immünoterapi modalitelerindeki gelişmelerle birlikte, metastatik hastalarda beklenen yaşam süreleri uzamıştır. ${ }^{[3]}$ Bu nedenle de kemik metastazlarının gelişme ve patolojik kırıkların görülme sıklığı artış göstermektedir. ${ }^{[4]}$

Hastaların cerrahi işlemlerden ne kadar yarar göreceği hakkında net bir fikir birliği yoktur. ${ }^{[5]}$ Pelvis ve periasetabular bölge metastazları, lezyonların yerleşim yeri ve boyutuna göre sınıflandırılmaktadır. ${ }^{[6-8]}$ Metastatik lezyonların sınıflaması yanında, hastaların genel durumlarının belirlenmesi ve beklenen yaşam sürelerinin tespiti de tedavi planlamasında önem arz eder. Beklenen yaşam süresi üç aydan fazla olan hastalarda, var olan kırık veya hayat kalitesini bozan şiddetli ağrı durumlarında invaziv işlemler, özellikle de cerrahi rezeksiyonlar gündeme gelir. Metastatik hastaların genel durumları ve beklenen sağkalım süreleri ile ilgili günümüzde kullanılan güncel sınıflama sistemleri şunlardir: Eastern Cooperative Oncology Group Performance ${ }^{[9]}$, Katagiri sınıflaması ${ }^{[10]}$, PathFx skorlama ${ }^{[11]}$ sistemi ve Capanna-Campanacci skorlaması. ${ }^{[12]}$

Metastatik kemik lezyonu olan hastalarda uygulanacak cerrahi işlemler -onkolojik rahatsızlıkları bulunmayan hastalara göre- daha yüksek oranda kanama, tespit yetmezliği, derin ven trombozu gibi komplikasyonlara sahiptir. Bu durum, cerrahi planlamada ve cerrahi öncesi hasta bilgilendirilmesinde mutlaka göz önünde tutulmalıdır.

Metastatik hastaların tedavi planlamasında multidisipliner bir yaklaşım gereklidir. Kemoterapi ve radyoterapi alan hastaların cerrahi tedavi zamanlama planları yapılırken, bu multidisipliner takım içinde, medikal onkolog ve radyasyon onkoloğu mutlaka yer almalıdır. Yapılacak cerrahi stabilizasyonun başarısını artırmak için, hastanın ameliyat öncesi aldığı ve ameliyat sonrası planlanan radyoterapi tedavisi hakkında fikir alınmalıdır.

Hastaların primer tanıları da, metastatik lezyonların tedavilerinde seçilecek yöntemin belirlenmesi ve olası komplikasyonları öngörme açısından önemlidir. Örneğin; tiroid ve renal hücreli kanser hastalarının ameliyat öncesi embolizasyonu veya pulmoner emboli riski yüksek hastalarda vena kava filtre uygulamaları için, girişimsel radyoloji ile konsültasyon gerekebilir. Bu hastaların genel durumlarının ameliyat sonrası daha da bozulabileceği akılda tutularak, ameliyat sonrası rehabilitasyon programları, mümkünse ameliyat öncesinde planlanmalıdır.

Metastatik hastaların tedavisinde, geniş cerrahi sınırların sağlanması için internal veya eksternal hemipelvektomi nadiren endikedir. Alt ekstremitenin fonksiyonel olmaması, kitlenin aşırı büyüklügüüne bağlı damar sinir invazyonu veya şiddetli ağrı, cerrahi sınır gözetilmeksizin hemipelvektomi endikasyonu oluşturabilir ${ }^{[13]}$ Pelvis metastatik lezyonlarının geniş cerrahi sınırlarla rezeksiyonunun, beklenen yaşam süresinin uzamasına etki etmesi, sadece renal hücreli tümörlerin soliter metastazlarında rapor edilmiştir. ${ }^{[14,15]}$ İnternal veya eksternal hemipelvektomi kararında, siyatik sinir, femoral sinir ve kalça ekleminin tutulumu etkilidir. Bu üç yapıdan ikisi tutulmuş ise, alt ekstremite fonksiyonel olarak kullanılamayacağı için amputasyon planlanmalıdır. İnternal hemipelvektomi, eksternal hemipelvektomiye göre daha fonksiyonel olmasına rağmen, cerrahiye bağlı komplikasyonlar ve daha uzun iyileşme süresi gibi dezavantajları vardır. ${ }^{[16]}$ Hemipelvektomi kararında; hastanın geride kalan sınırlı yaşam süresi, yapılacak işlemin morbiditesi, mortalitesi ve ameliyat sonrası rehabilitasyon süresi dikkate alınmalıdır. ${ }^{[13]}$

\section{Lezyonların Pelvisteki Yerleşimine Göre Sınıflandırılması}

Pelvisteki lezyonların tedavisinde, lokalizasyon ve metastatik lezyonun osteolitik veya osteoblastik olması tedavi planlamasında önemlidir. Metastatik pelvis lezyonları; yük taşıyan alanlar (periasetabular ve sakral bölge) ile yük taşımayan alanlar (iliak kanat ve pubis bölgesi) olarak kabaca sınıflandırılabilir. ${ }^{[17]}$ Yük taşımayan alanlardaki lezyonlarda nadiren cerrahiye ihtiyaç duyulurken, yük taşıyan alanlardaki lezyonlar cerrahi tedaviden yarar görür.

Lezyon yerleşimlerinin Enneking tarafından tanımlanmış sınıflaması pelvisi dört bölgeye ayırır (Şekil 1). ${ }^{[6]}$ Birinci ve üçüncü bölge yük taşımayan, ikinci ve dördüncü bölge ise yük taşıyan olarak sınıflandırılır. Periasetabular bölge lezyonları, ikinci bölgede sınıflandırılmış olup, pelvik halkanın mekanik bütünlüğünü zaman içinde bozar ve hastanın kalça eklemini zaman içinde harap eder. İkinci bölge lezyonları, kendi içinde, Harrington tarafindan ayrıca sınıflandırılmıştır. ${ }^{[7]}$ Birinci ve üçüncü bölgedeki lezyonlar ise osteolitik karakterde olsalar bile, pelvik halkanın mekanik stabilitesine etki etmeyen lezyonlar olarak sınıflandırılabilir. ${ }^{[18]}$

Lezyonların yerleşimlerinin tespiti, tedavi planlaması için çok önemlidir. Rutin pelvis direkt grafileri, lezyonların kesin sınırlarını tespit etmekte yetersiz kalabilmektedir. Bu nedenle, hastalarda bilgisayarlı tomografi (BT) veya üç boyutlu BT tetkikleri ve manyetik rezonans (MR) görüntüleme yararlı olacaktır. Ameliyatta kullanılacak cerrahi yaklaşımın seçimi ve kullanılacak implantın planlaması için de lezyonların yeri ve büyüklüğünün tespiti çok önemlidir. MR görüntüleme ayrıca, metastatik lezyonların yumuşak dokulara komşuluklarını, 


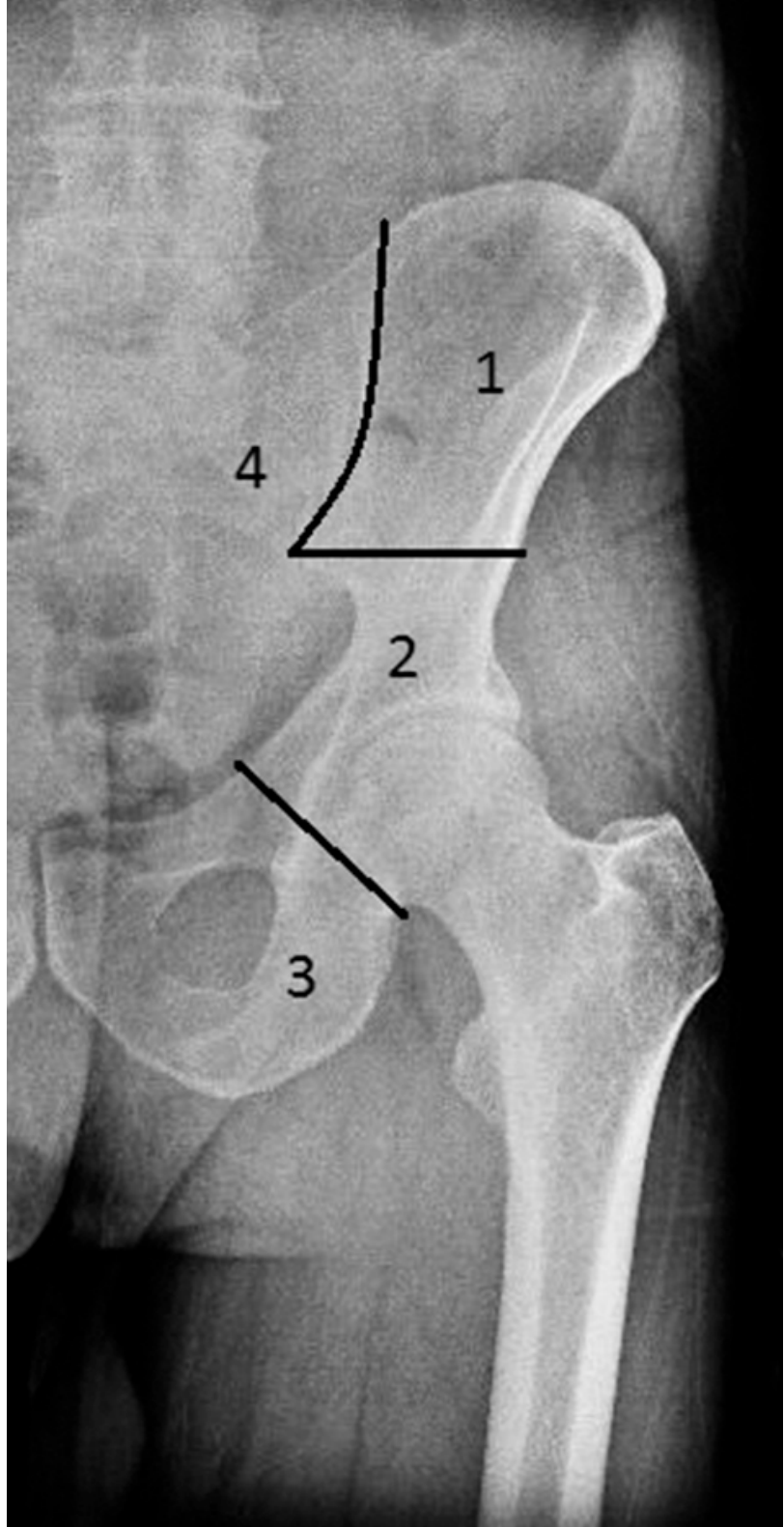

Şekil 1. Enneking'in tanımlamış olduğu, pelvik bölge metastazlarının yerleşim yerlerine göre sınıflandırılması. ${ }^{[6]}$ nörovasküler yapılara yakınlıklarını veya invazyonunu göstermede çok başarılıdır. Pelvis bölgesinde epidural anestezi kullanımı, hem ameliyat esnasında kanamayı azaltır hem de ameliyat sonrası ağrı kontrolü için tercih edilen yöntemdir. Ameliyat sonrası cerrahi sahanın kapatılması güç olabilir ki bu durumda plastik cerrahlardan yardım istenebilir. Ayrıca, hastaların hem genel olarak düşkün olmaları hem de yapılan cerrahinin büyüklüğü nedeniyle, ameliyat sonrası dönemde yoğun bakım ünitesinde takipleri gerekebilir.

\section{Hastaların Sınıflanması}

Cerrahi tedavi planlanmasında, kararın ortopedik cerrah, radyasyon onkoloğu ve medikal onkoloğun bulunduğu multidisipliner bir ekip tarafindan değerlendirilmesi uygun olacaktır. Uzun kemik metastazları olan hastalar için bir sınıflama, 2001 yılında Capanna ve Campanacci tarafından tanımlanmıştır: Sınıf 1, iyi prognozlu soliter lezyonlar; Sınıf 2, patolojik kırık bulunan hastalar; Sınıf 3, kırık ihtimali yüksek lezyonlar; Sınıf 4 ise diğer lezyonlar olarak sayılabilir (Tablo 1). ${ }^{[12]}$

Uygun tedaviyi belirlemede; beklenen yaşam süresi, tümörün tipi ve evresi, iç organ yayılımı, primer lezyon ile metastaz saptanması arasında geçen süre, patolojik kırık gelişme riski ve tümörün kemoterapi, radyoterapi veya diğer cerrahi dışı modalitelere yanıtı etkendir. Capanna, pelvis metastazlarının tedavisinde hastanın prognozu (Capanna Sınıf 1-4), lezyonun yeri (Enneking zonları 1-3) ve periasetabular bölgedeki kemik kaybı miktarına göre bir tedavi algoritması önermiştir (Şekil 2). ${ }^{[12]}$

Tüm Sınıf 1, 2 ve 3 hastalar, öncelikle cerrahi tedavi için ortopedik onkoloğa yönlendirilmeli ve cerrahi sonrası kemoterapi ve radyoterapi planlanmalıdır. Sınıf 4 hastalar için ise öncelikle cerrahi dışı tedavi yöntemleri göz önünde bulundurulmalıdır.

\section{Asetabulum Dışı Lezyonlar}

Bunlar, iliak kanat, pubis veya iskion kolu izole kırıkları olup, genellikle majör cerrahi yapılmadan

Tablo 1. Pelvis metastatik lezyonları olan hastaların Capanna tarafından sınıflandırılması ${ }^{[2]}$

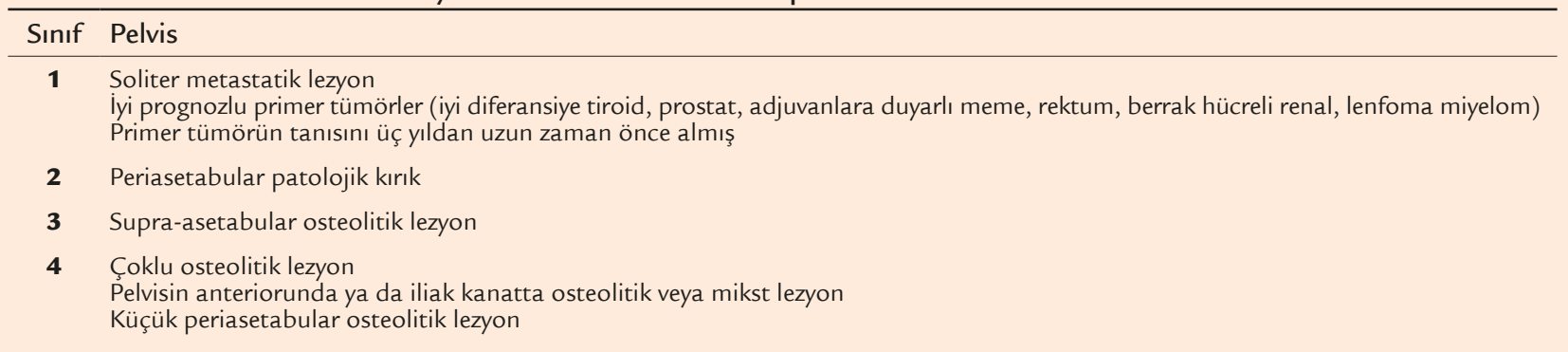




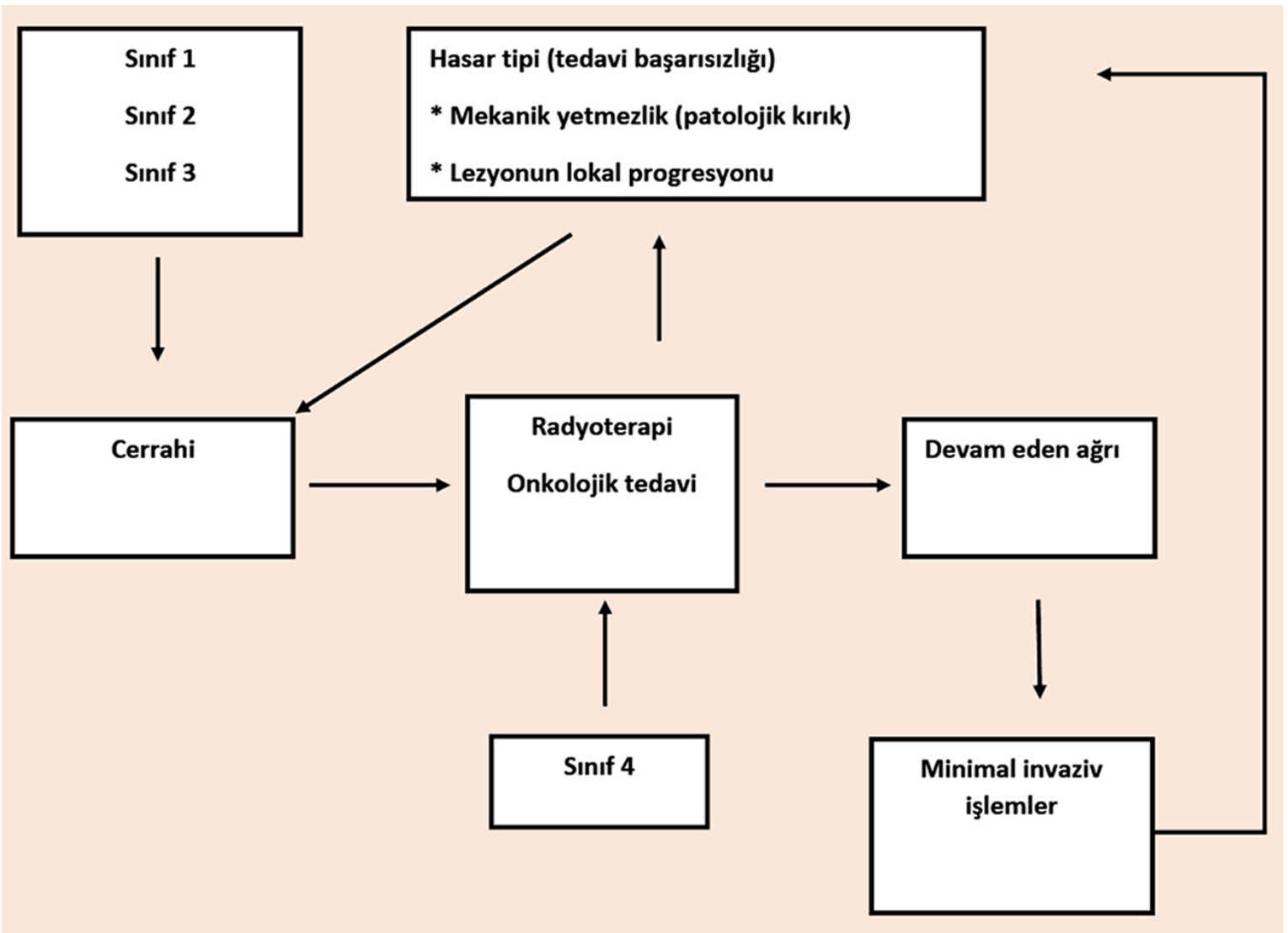

Şekil 2. Capanna'nın sınıflamasına göre konservatif-cerrahi tedavi algoritması. ${ }^{[12]}$

tedavi edilebilir. Bu alanlardaki kırıklar pelvik halka bütünlüğünü bozmaz ve yük vermeye engel teşkil etmez. Bu bölge lezyonlarındaki ağrı, kırıktan ziyade genellikle tümörün kendisine bağlıdır. Bu nedenle, hastalar radyofrekans ablasyon, embolizasyon, radyoterapi, kemoterapi ve bisfosfonatlarla tedavi edilebilirler. ${ }^{[17,19]} \mathrm{Bu}$ tedavilere inatçı lezyonlara ise, periasetabular bölgeden daha az morbidite yaratan, cerrahi rezeksiyonlar uygulanabilir. Proksimal bölge lezyonları için iliofemoral veya ilioinguinal yaklaşımlar, pubik bölge için Pfannenstiel insizyon kullanılabilir. Yük taşımayan alanların rezeksiyonları sonrası rekonstrüksiyona ihtiyaç duyulmaz. Ayrıca, rezeksiyonları takiben erken veya geç dönemde ortaya çıkabilecek abdominal ve pelvik hernilerin engellenmesi ve erken dönemdeki yara yeri problemlerinin önlenmesi için, cerrahi alanın kapatılmasına özen gösterilmeli, gerekirse yumuşak doku rekonstrüksiyon teknikleri kullanılmalıdır. ${ }^{[17]}$

Enneking Tip 4 metastatik lezyonların cerrahi tedavisi, bölge anatomisinin karmaşıklığı, damar ve sinir köklerinin tümoral lezyonlara yakınlığı nedeniyle zordur. ${ }^{[13]}$
Eğer lezyon sakroiliak eklemi ilgilendirmiyorsa, küretaj ve oluşan kavitenin kemik çimentosu ile doldurulması veya rezeksiyon ile tedavi edilebilir. Lezyon sakroiliak eklemi ilgilendirdiğinde ise, tedavi seçiminde eklem tutulumunun miktarı önemlidir. Eklemin \%50'sinden fazla bir alanda tutulum var ise, sadece rezeksiyon pelvik halka instabilitesine yol açacağı için, plak veya spinal vidalarla tespit gerekecektir; \%50'den daha az rezeksiyonlarda ise genellikle tespite ihtiyaç duyulmaz. Ayrıca, S1 seviyesinin altındaki rezeksiyonlar yapısal olarak stabil sayılır ve ilave bir rekonstrüksiyon gerekmez.

\section{Periasetabular Lezyonlar}

Bu bölgede, tümörün kitle etkisi, kıkırdak lezyonları, yük verme veya hareket esnasında ortaya çıkan ağrılar gibi birçok faktör ağrıya neden olabilir. Bu nedenle, bu eklem dışı bölgelere göre asetabular bölge lezyonları daha agresif cerrahi tedaviye ihtiyaç gösterebilir. Patolojik kırık gelişmesi cerrahi tedavi için kesin endikasyon olmasına rağmen, hastanın genel durumu ve cerrahiye kontrendikasyon yaratan diğer durumlar göz ardı edilmemelidir. Diğer metastatik lezyonlarda 
Tablo 2. Harrington periasetabular bölge metastatik lezyonlarının sınıflaması ${ }^{[7]}$

\begin{tabular}{|c|c|c|}
\hline Sinıf & Lezyonları yerleşim yeri & Önerilen tedavi \\
\hline 1 & $\begin{array}{l}\text { Asetabulumu ilgilendiren ancak mediyal, lateral ve } \\
\text { superior korteksler sağlam }\end{array}$ & Küretaj + primer çimentolu kalça protezi \\
\hline 2 & $\begin{array}{l}\text { Mediyal duvarda defekt olup superior ve lateral } \\
\text { korteksler sağlam }\end{array}$ & Antiprotrüzyo kafes ve çimentolu total kalça protezi \\
\hline 3 & Superior, lateral ve mediyal kortekslerde defekt mevcut & $\begin{array}{l}\text { Steinmann çivileri ile çimento ve antiprotrüzyo kafes uygulamasının } \\
\text { ardından çimentolu total kalça protezi } \\
\text { Eyer tarzı (saddle) protez }\end{array}$ \\
\hline 4 & $\begin{array}{l}\text { Pelvis devamlılı̆ını bozan asetabulum inferior } \\
\text { korteksinde de defekt mevcut }\end{array}$ & $\begin{array}{l}\text { Eyer tarzı (saddle) protez } \\
\text { Allogreft ile asetabular rekonstrüksiyon ve total kalça protezi uygulaması }\end{array}$ \\
\hline
\end{tabular}

Tablo 3. Periasetabular lezyonların modifiye AAOS* sınıflaması ve önerilen tedavi yaklaşımları ${ }^{[17]}$

\begin{tabular}{|c|c|c|}
\hline Tip & Asetabular hasar şekli & Önerilen tedavi \\
\hline $\mathbf{0}$ & Subkondral alana ulaşmayan, eklem dışı lezyonlar & Küretaj ve çimentolama \\
\hline 1 & $\begin{array}{l}\text { Eklem içi lezyon mevcut ancak asetabulum çatısı, } \\
\text { mediyal ve lateral korteksler sağlam }\end{array}$ & Çimentolu primer total kalça protezi ve defektlerin çimentolanması \\
\hline 2 & Mediyal duvarda defektif lezyon varlığı & Antiprotrüzyo kafes + çimento +/- greftleme, \\
\hline 3 & $\begin{array}{l}\text { Asetabulum çatısı ve lateral kortekste defektif lezyon } \\
\text { ancak posterior kolon tutulmamış }\end{array}$ & $\begin{array}{l}\text { Steinman çivileri + çimento ile asetabular rekonstrüksiyon + çimentolu } \\
\text { kalça protezi }\end{array}$ \\
\hline 4 & $\begin{array}{l}\text { Tip } 3 \text { defektlere ek olarak asetabulum inferiorda } \\
\text { defektif lezyon varlığı }\end{array}$ & $\begin{array}{l}\text { Steinman çivileri (iskion pubis koluna tespit sağlamalı) + çimento ile } \\
\text { asetabular rekonstrüksiyon }+ \text { çimentolu kalça protezi }\end{array}$ \\
\hline 5 & $\begin{array}{l}\text { Pelvis devamlılı̆̆ bozulmuş ve posterior kolon } \\
\text { devamlılığı olmayan masif asetabulum tutulumu }\end{array}$ & $\begin{array}{l}\text { Rezeksiyon artroplastisi } \\
\text { İskiofemoral füzyon } \\
\text { Eyer tarzı (saddle) protez } \\
\text { Asetabular allogreft ile rekonstrüksiyon }\end{array}$ \\
\hline
\end{tabular}

* American Academy of Orthopaedic Surgeons

olduğu gibi sadece osteosentez yapmak, bu bölgedeki metastazları tedavi etmeyecektir. Periasetabular metastazlar genellikle artroplasti ve asetabular rekonstrüktif işlemler ile tedavi edilmektedir. Tedavideki hedef hastanın mobilizasyonunun sağlanması ve ağrısının giderilmesidir. Hastanın beklenen yaşam süresi ve cerrahiden yarar görüp görmeyeceği, cerrahi öncesi medikal onkolog ile tartışılmalıdır. Bu bölge lezyonlarının tam olarak yayılımı, lokalizasyonu, boyutları bilinmeli ve rekonstrüktif işlemler buna göre planlanmalıdır. Asetabular bölge metastatik lezyonlarının tedavisi, primer çimentolu total kalça protezlerinden, çimento - Steinman çivi, antiprotrüzyo kafesleri, üç ayaklı rekonstrüksiyon kafesleri veya bunların kombinasyonunu içeren birçok farklı cerrahi teknik ile gerçekleştirilebilir. Kemik çimentosu, protezin komponentlerine erken dönemde yeterli stabilite sağlaması ve kemoterapi/radyoterapiden etkilenmemesi nedeniyle, bu bölgenin rekonstrüksiyonlarında vazgeçilmez tespit materyalidir.

Periasetabular metastatik lezyonların sınıflamasında ve tedavi planlamasında kullanılan sistem, 1981 yılında Harrington tarafindan tanımlanmıştır (Tablo 2). ${ }^{[7]}$
Ayrıca AAOS (American Academy of Orthopaedic Surgeons) tarafindan ortaya konulan ve Harrington sistemine benzer özellikler taşıyan sınıflamada ise, hastalar lezyonların lokalizasyonlarına göre Tip 0 ile Tip 5 arasında sınıflandırılmaktadırlar (Tablo 3). ${ }^{[17,20]}$

Bu bölge lezyonlarının sınıflamasında en sık kullanılan Harrington sınıflaması ve önerilen tedavi modaliteleri şu şekildedir:

Tip 1 lezyonlar asetabulumu ilgilendiren ancak mediyal, lateral ve superior kortekslerin salim kaldığı lezyonlardır. Standart çimentolu asetabular komponent içeren total kalça protezleri ile cerrahi tedavi düzenlenir. Son yıllarda trabeküler metal içeren komponentlerin kullanımına ait yayınlar da mevcuttur. Ancak, ameliyat sonrası dönemde radyoterapi uygulanabileceğinden, çimentolu komponentlerin kullanılması daha uygun olacaktır.

Tip 2 lezyonlar ise mediyal duvarda defekt bulunan lezyonlardır. Bu hastalarda asetabulumun superioru (çatısı) ve lateral duvarı korunmuştur. Bu lezyonların tedavisinde, asetabular komponentlerin yeterli stabilizasyonu sağlayamaması nedeniyle, primer total kalça protezleri 
uygulanamamaktadır. Bu lezyonların cerrahisinde, tümör dokusunun küretajı sonrası defekt hâlâ Tip 2 ise antiprotrüzyo kafesler, mediyal duvara meş uygulaması veya pubis ve iskion kollarına gönderilen Steinman pinleri ile kombine edilen çimento rekonstrüksiyonu ve çimentolu asetabular komponent uygulanabilir.

Tip 3 lezyonlar ise superior, mediyal ve de lateral kortekste defekt bulunan lezyonlardır. Bu lezyonlarda asetabulumun ön veya arka kolonlarından biri ile superioru etkilenmiştir; hastaların bir kısmında inferior kısım da tutulur. Dolayısıyla, bu grupta primer artroplasti veya antiprotrüzyo kafeslerin kullanılması stabil bir tespit sağlamaz. Harrington, bu tip hastalar için; uzun yivli Steinman çivileri ve kemik çimentosu ile asetabulumun rekonstrüksiyonu ve üzerine çimentolu asetabular komponent yerleştirilmesi şeklinde bir teknik tanımlamıştır. Tümör rezeksiyonu sonrası orijinal asetabulum, pelvisin sağlam kalan bölgelerine gönderilen Steinman çivileri ve çimento ile rekonstrükte edilmelidir. ${ }^{[21,22]}$ Sonrasında, çimentolu asetabular komponent, antiprotrüzyo kafes veya üç bacaklı kafes uygulanabilir (Şekil 3 ve 4). Yumuşak doku rezeksiyon miktarına bağlı olarak "constrained" asetabular komponentler tercih edilebilir.

Tip 4 lezyonlar ise pelvis devamlılığını bozan asetabulumun inferior kısmında defekt oluşturan lezyonlardır. Patolojik tutulum, asetabulumun superioru ile birlikte her iki kolonu da ilgilendiren bölgededir. Lezyonların rezeksiyonu ve sonrasında sarsak kalça, asetabular allogreftler veya pelvik protezler (tantalyum içerikli protezler, dondurma külağı veya eyer [saddle] tipi protezler) ile tedavileri düzenlenebilir (Şekil 5 ve 6 ).

Hastaların lezyonlarının yerleşimleri ve tedavileri ile ilgili her üç sınıflamaya ait veriler Tablo 2, 3 ve 4'te özetlenmiştir.

\section{MINIMAL INVAZIV TEDAVILER}

Cerrahi tedaviden yarar görmeyecek veya pelvik halka bütünlügünü bozmayan lezyonlar için hastaların hayat kalitesini artırmaya yönelik çeşitli yöntemler bildirilmiştir.

\section{Radyoterapi}

En sık kullanılan girişimsel olmayan tedavi yöntemidir. Hastaların \%20-80'inin ağıı şikâyetinde tama yakın gerileme olduğuna dair yayınlar mevcuttur. ${ }^{[23]}$ Bu nedenle, pelvis metastatik lezyonlarının cerrahi yapılmayan olgularında standart olarak kullanılan yöntemdir.

Radyoterapinin etkin olmadığı lezyonlarda veya yan etkileri nedeniyle kullanılamadığı hastalarda, son yıllarda çeşitli perkütan yöntemlerle tümör dokusunun harap edilmesine dayalı bazı tedaviler geliştirilmiştir. Bunlar arasında; etanol uygulaması, lazer yardımlı termoterapi, kriyoablasyon ve radyofrekans ablasyon sayılabilir. ${ }^{[24]}$

\section{Etanol ve Termoterapi}

Kolay ve maliyet etkin tekniklerdir. BT altında lezyona perkütan etanol enjeksiyonu veya lazer destekli ISI probları uygulaması ile tümör dokusu harap edilir. ${ }^{[25,26]}$

\section{Kriyoablasyon}

Özellikle prostat dokusunda kullanılan ve hızlı bir şekilde lezyonların dondurulmasına dayanan bir yöntemdir. Sıvı nitrojen kullanılarak hızlı bir şekilde dokuları soğutup hücre içi yapıların kristalleşmesi ve hücre zarının bozulması amaçlanır. Böylelikle $2 \mathrm{~cm}$ 'ye kadar ulaşan doku penetrasyonu sağlanabilir. Ozmotik değişiklikler sayesinde canlı dokuların ölümü ile lezyonları tedavi eden ve özellikle ağrılı kemik tümörlerinde kullanılan etkili bir yöntemdir. ${ }^{[27]}$

\section{Radyofrekans Ablasyon}

BT eşliğinde yüksek frekans alternatif akım kullanılarak, doğrudan lezyonların içine bir iğne yardımıyla uygulanır. Metastatik lezyona uygulanan yüksek dereceli ısı ile hastaların ağrı şikâyetlerinde belirgin azalma olduğu bildirilmiştir. ${ }^{[28]}$

\section{Asetabuloplasti}

Asetabulum çevresindeki osteolitik alanlara vertebroplasti tekniğine benzer şekilde kemik çimentosu uygulamasıdır. ${ }^{[29]}$ Polimetilmetakrilat en sık kullanılan ajan olup, $80-120^{\circ} \mathrm{C}$ 'ye kadar ısınarak kansellöz kemikte 1,5-2 mm'lik, kortikal kemikte 0,5 mm'lik penetrasyon sağlar. Çimento uygulaması ile, hem mekanik destek hem de ısı etkisi ile tümör dokusunun nekrozu sağlanır.

\section{KOMPLIKASYONLAR}

Cerrahiye bağlı komplikasyon oranı, rutin ortopedik rekonstrüktif işlemlere göre daha fazladır. Ameliyat dönemi mortalite ve komplikasyon oranını sırasıyla \%3 ve $\% 19,5$ olarak belirten yayınlar literatürde mevcuttur. ${ }^{[30]}$ Belli başlı komplikasyonlar arasında; kanama, sinir hasarları, mesane ve barsak yaralanmaları, yara yeri sorunları, enfeksiyonlar, protez dislokasyonları, herniler sayılabilir. ${ }^{[13]}$

Perkütan uygulanan minimal invaziv işlemlerde komplikasyon oranları cerrahi tekniklere göre daha nadirdir. Enfeksiyon oranları ve yara yeri sorunları oldukça nadirdir. Asetabuloplastide kemik çimentosunun eklem içine kaçması, radyofrekans ablasyon ve kriyoterapi işlemlerinde ise damar sinir yapılarına $1 \mathrm{~cm}$ 'den yakın olan lezyonlarda damar sinir hasarları, bu tekniklerin komplikasyonları arasında sayılabilir. ${ }^{[18]}$ 

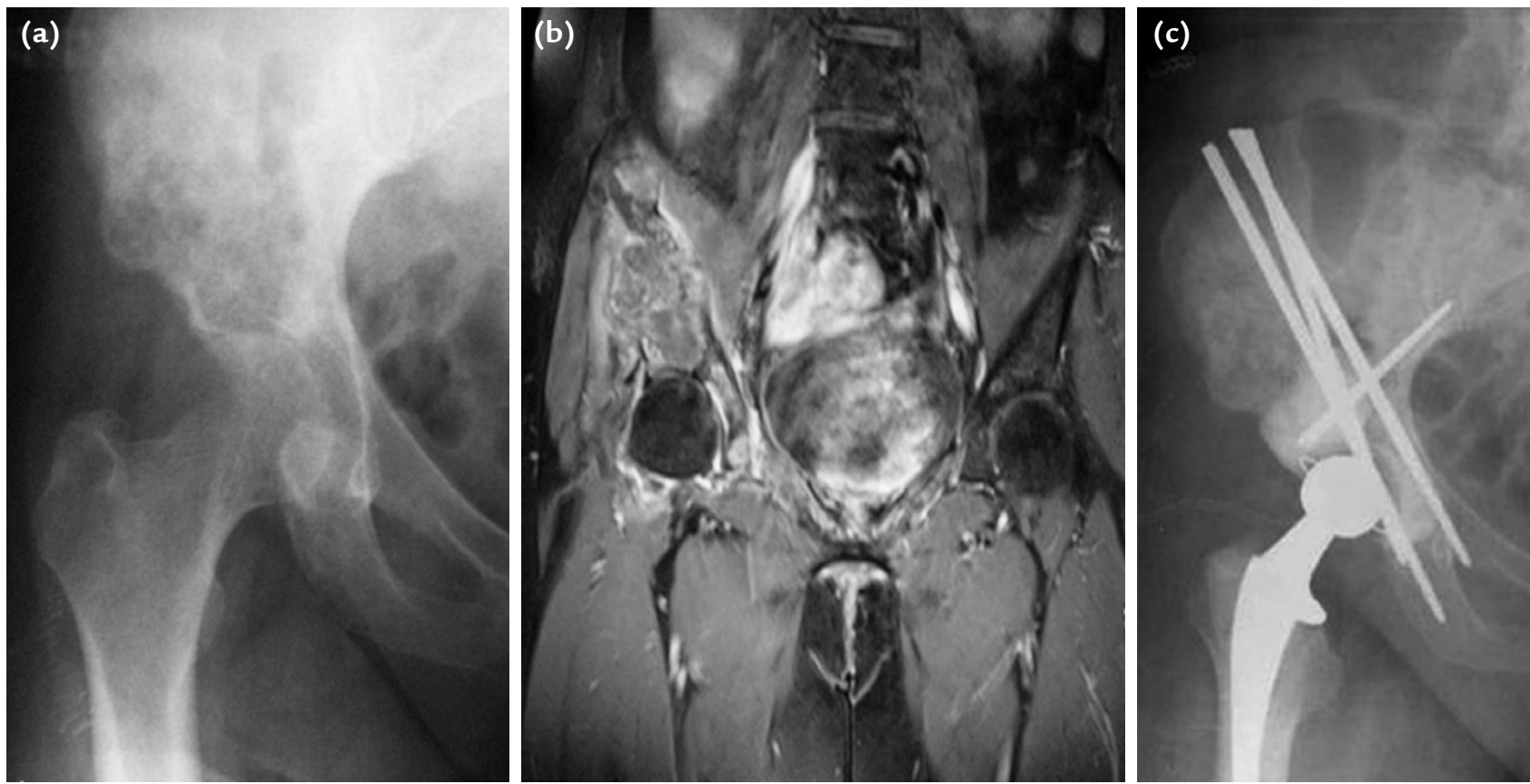

Şekil 3. a-c. Altmış dört yaşında erkek, metastatik akciğer kanseri hastasının, ameliyat öncesi direkt grafi görüntüsü (a), ameliyat öncesi MR görüntüsü (b) ve Harrington rekonstrüksiyonu sonrası X-ray görüntüsü (c).
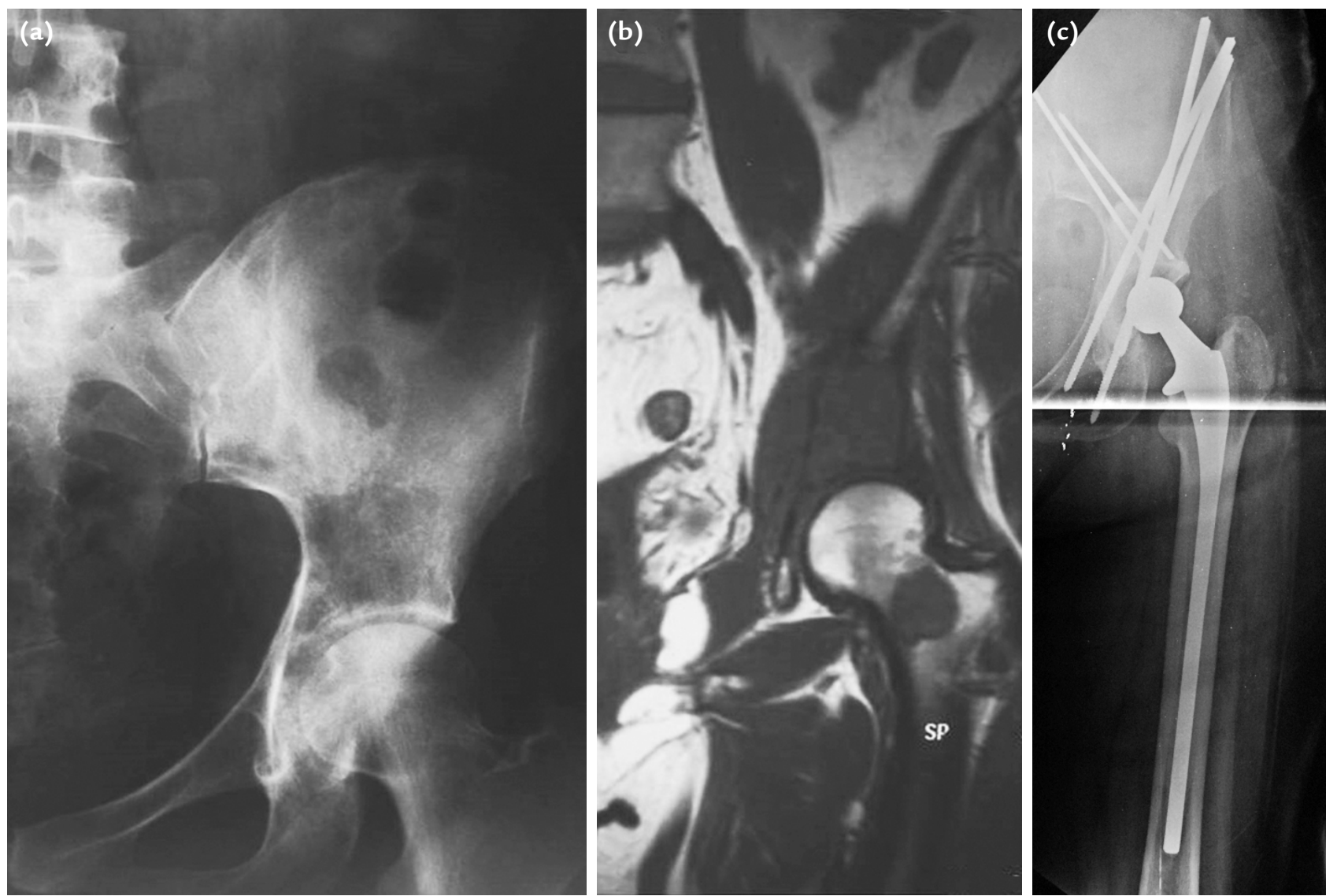

Şekil 4. a-c. Elli dokuz yaşında kadın, metastatik meme kanseri hastasının, ameliyat öncesi direkt grafi görüntüsü (a), ameliyat öncesi MR görüntüsü (b) ve Harrington rekonstrüksiyonu sonrası direkt grafi görüntüsü (c). 

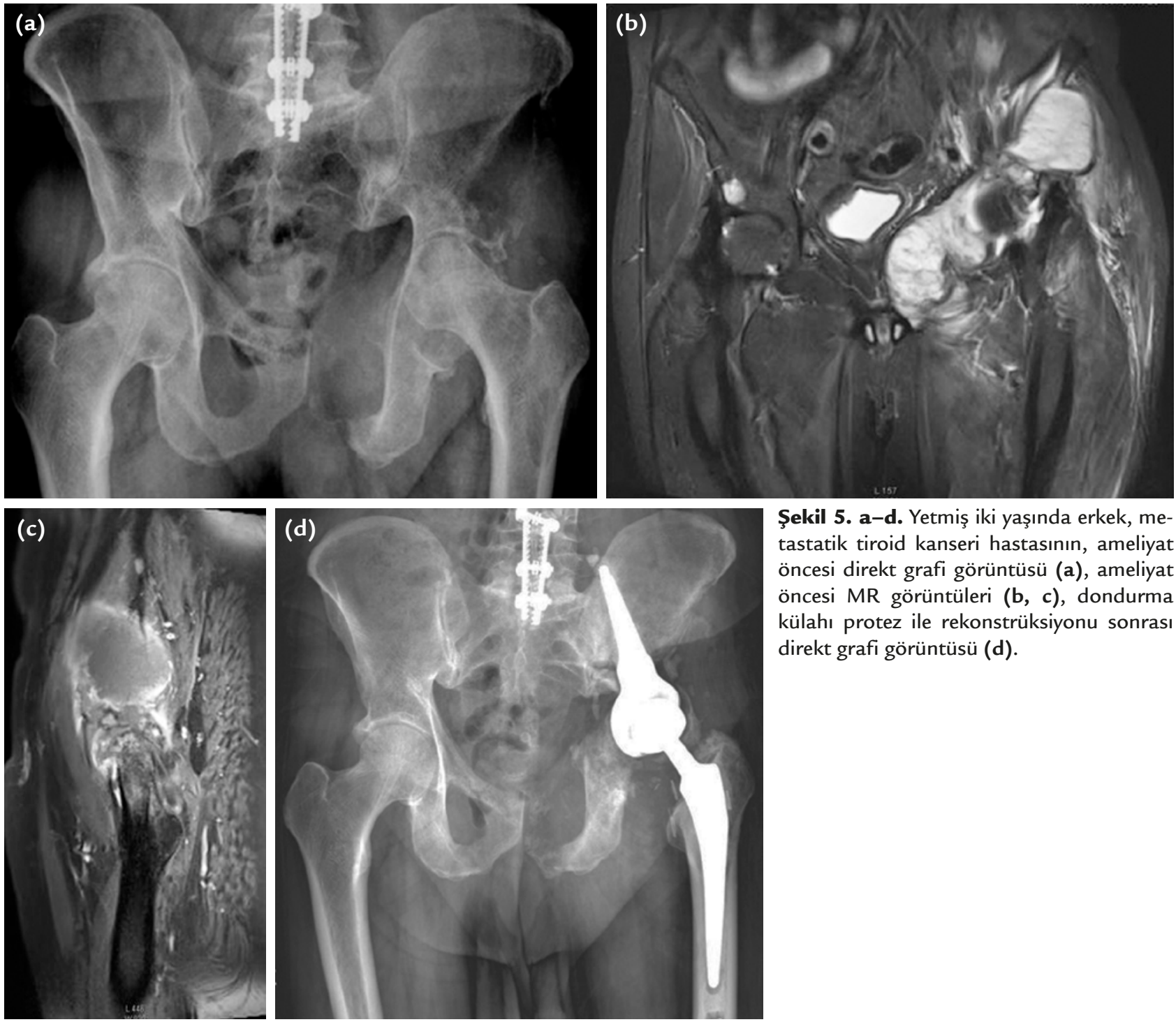

Şekil 5. a-d. Yetmiş iki yaşında erkek, metastatik tiroid kanseri hastasının, ameliyat öncesi direkt grafi görüntüsü (a), ameliyat öncesi MR görüntüleri $(b, c)$, dondurma külahı protez ile rekonstrüksiyonu sonrası direkt grafi görüntüsü (d).

\section{SONUÇ}

Pelvis metastatik lezyonları, onkoloji alanındaki diğer gelişmelere paralel olarak artmaktadır. Tedavideki birincil amaç; patolojik kırıkların tedavisi, ağrının azaltılması, hareketin veya alt ekstremiteye yük verebilmenin sağlanmasıdır. Bu nedenle, yapılacak müdahalenin belirlenmesi; primer hastalığın prognozuna, kemik defektinin yerleşim yerine, boyutuna ve neo-adjuvan tedaviye vereceği yanıta bağlıdır. Bazı soliter metastazlarda, geniş rezeksiyon ile beklenen sağkalım süresi artırılabilir. İliak kanat lezyonları, eklemde destrüksiyon yaratmayan periasetabular lezyonlar, iskion ve pubik kollardaki lezyonlar genellikle radyoterapi ile tedavi edilirlerken, bu tedavi ile başarı sağlanamaz ise minimal invaziv işlemler veya cerrahi rezeksiyonlar düşünülebilir. Asetabular bölge lezyonlarında ise, genellikle cerrahi rekostrüksiyonlar ile hastaların ağrılarında azalma ve hareket kabiliyetlerinde artma sağlanmaktadır.

Hastalar, genel durumlarına göre hayat kalitelerinin artırılması için değerlendirilmelidir. Hasta hakkında en uygun palyatif tedavi kararı, ortopedik onkolog, medikal onkolog ve radyasyon onkoloğundan oluşan bir grup tarafindan verilmelidir. Bu derleme yazısında bahsedilen sınıflama sistemleri, ilgili hasta grubu hakkında karar verirken, aşırı veya yararsız tedavi düzenlemelerini önlemek adına yardımcı olabilir. 

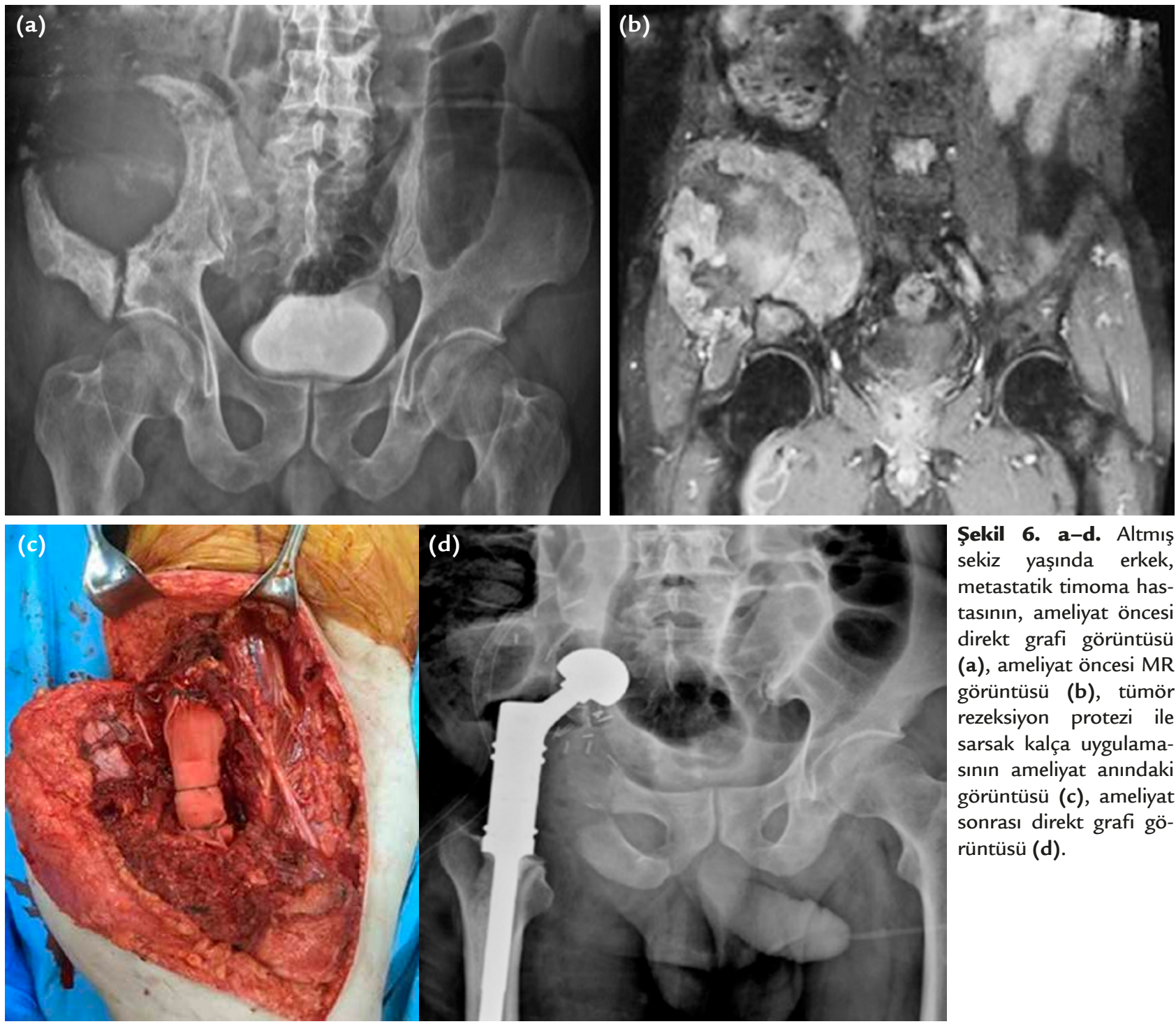

Şekil 6. a-d. Altımış sekiz yaşında erkek, metastatik timoma hastasının, ameliyat öncesi direkt grafi görüntüsü (a), ameliyat öncesi MR görüntüsü (b), tümör rezeksiyon protezi ile sarsak kalça uygulamasının ameliyat anındaki görüntüsü (c), ameliyat sonrası direkt grafi görüntüsü (d).

Tablo 4. Capanna sınıflama sistemine göre cerrahi teknik planlama özeti ${ }^{[12]}$

\begin{tabular}{|c|c|c|c|}
\hline Hasta sınıfi & Lezyon yeri (Enneking) & Rezeksiyon & Rekonstrüksiyon \\
\hline Sinıf 1 & Zone 1,3 & Geniş & Gerek yok \\
\hline Sinıf 1 & Zone 2 & Geniş & $\begin{array}{l}\text { Harrington prodesürü } \\
\text { Tümör protezi } \\
\text { Eyer tarzı (saddle) protez } \\
\text { Masif allogreft ile total kalça protezi }\end{array}$ \\
\hline Sinıf 2, 3 & Zone 2 & $\begin{array}{c}\text { Marjinal, } \\
\text { intralezyoner }\end{array}$ & $\begin{array}{l}\text { Harrington Tip } 1 \text { Defekt } \\
\text { - Küretaj + çimento } \\
\text { - Primer total kalça protezi } \\
\text { Harrington Tip } 2 \text { Defekt } \\
\text { - Antiprotrüzyo kafes + total kalça protezi } \\
\text { Harrington Tip } 3 \text { Defekt } \\
\text { - Harrington prosedürü } \\
\text { - Defektlere sement veya greft uygulama sonrası total kalça protez } \\
\text { Harrington Tip } 4 \text { Defekt } \\
\text { - Tümör protezi } \\
\text { - Eyer tarzı (saddle) protez } \\
\text { - Masif allogreft ile total kalça protezi }\end{array}$ \\
\hline
\end{tabular}




\section{KAYNAKLAR}

1. Damron TA, Sim FH. Surgical treatment for metastatic disease of the pelvis and the proximal end of the femur. Instr Course Lect 2000;49:461-70.

2. Aboulafia AJ, Levine AM, Schmidt D, Aboulafia D. Surgical therapy of bone metastases. Semin Oncol 2007;34(3):20614. Crossref

3. Hage WD, Aboulafia AJ, Aboulafia DM. Incidence, location, and diagnostic evaluation of metastatic bone disease. Orthop Clin North Am 2000;31(4):515-28. Crossref

4. Li S, Peng Y, Weinhandl ED, Blaes AH, Cetin K, Chia VM, Stryker S, Pinzone JJ, Acquavella JF, Arneson TJ. Estimated number of prevalent cases of metastatic bone disease in the US adult population. Clin Epidemiol 2012;4(1):87-93. Crossref

5. Mac Niocaill RF, Quinlan JF, Stapleton RD, Hurson B, Dudeney S, O'Toole GC. Inter- and intra-observer variability associated with the use of the Mirels' scoring system for metastatic bone lesions. Int Orthop 2011;35(1):83-6. Crossref

6. Enneking W, Dunham W, Gebhardt M, Malawar M, Pritchard D. A system for the classification of skeletal resections. Chir Organi Mov 1990;75(1 Suppl):217-40.

7. Harrington KD. The management of acetabular insufficiency secondary to metastatic malignant disease. J Bone Joint Surg Am 1981;63(4):653-64. Crossref

8. Harrington $\mathrm{KD}$, Orthopaedic management of extremity and pelvic lesions. Clin Orthop Relat Res 1995;(312):136-47.

9. Oken MM, Creech RH, Tormey DC, Horton J, Davis TE, McFadden ET, Carbone PP. Toxicity and response criteria of Eastern Cooperative Oncology Group. Am J Clin Oncol 1982;5(6):649-56. Crossref

10. Katagiri $H$, Takahashi M, Wakai $K$, Sugiura $H$, Kataoka T, Nakanishi K. Prognostic factors and scoring system for patients with skeletal metastasis. J Bone Joint Surg $\mathrm{Br}$ 2005;87-B(5):698-703. Crossref

11. Piccioli A, Spinelli MS, Forsberg JA, Wedin R, Healey JH, Ippolito V, Daolio PA, Ruggieri P, Maccauro G, Gasbarrini A, Biagini R, Piana R, Fazioli F, Luzzati A, Di Martino A, Nicolosi F, Camnasio F, Rosa MA, Campanacci DA, Denaro V, Capanna R. How do we estimate survival? External validation of a tool for survival estimation in patients with metastatic bone disease-decision analysis and comparison of three international patient populations. BMC Cancer 2015;15(1):424. Crossref

12. Capanna R, Campanacci DA. The treatment of metastases in the appendicular skeleton. J Bone Joint Surg Br 2001;83$B(4): 471-81$. Crossref

13. Hegde V, Bernthal NM. Metastatic Bone Disease: Pelvis. In: Randall RL, editor. Metastatic Bone Disease. New York: Springer; 2016. pp.267-77. Crossref

14. Lin PP, Mirza AN, Lewis VO, Cannon CP, Tu SM, Tannir NM, Yasko AW. Patient survival after surgery for osseous metastases from renal cell carcinoma. J Bone Joint Surg Am 2007;89(8):1794-801. Crossref

15. Fottner A, Szalantzy M, Wirthmann L, Stähler M, BaurMelnyk A, Jansson V, Dürr HR. Bone metastases from renal cell carcinoma: patient survival after surgical treatment. BMC Musculoskelet Disord 2010;11(1):145. Crossref
16. Lee Jr CM, Alt LP. Hemipelvectomy and hip disarticulation for malignant tumors of the pelvis and lower extremity. Ann Surg 1953;137(5):704-17. Crossref

17. Goodman HJ, Patterson FR. Surgical Management of Lower Extremity Metastatic Disease. In: Biermann JS, editor. Orthopaedic Knowledge Update: Musculoskeletal Tumors, 3rd ed. Rosemont: AAOS; 2014. pp.345-354.

18. Müller DA, Capanna R. The Surgical Treatment of Pelvic Bone Metastases. Adv Orthop 2015;2015:525363. Crossref

19. Hoffmann RT, Jakobs TF, Trumm C, Weber C, Heimberger TK, Reiser MF. Radiofrequency ablation in combination with osteoplasty in the treatment of painful metastatic bone disease. J Vase Interv Radiol 2008;19(3):419-25. Crossref

20. Ghert M, Alsaleh K, Farrokhyar F, Colterjohn N. Outcomes of an anatomically based approach to metastatic disease of the acetabulum. Clin Orthop Relat Res 2007;459:122-27. Crossref

21. Tillman RM, Myers GJ, Abudu AT, Carter SR, Grimer RJ. The three-pin modified 'Harrington' procedure for advanced metastatic destruction of the acetabulum. J Bone Joint Surg $\mathrm{Br}$ 2008;90-B(1):84-7. Crossref

22. Erol B, Aydemir AN, Onay T, Topkar MO. Reconstruction of advanced periacetabular metastatic lesions with modified Harrington procedure. Acta Orthop Traumatol Turc 2016;50(2):178-85. Crossref

23. Bates T. A review of local radiotherapy in the treatment of bone metastases and cord compression. Int J Radiat Oncol Biol Phys 1992;23(1):217-21. Crossref

24. Cadossi R, Ronchetti M, Cadossi M. Locally enhanced chemotherapy by electroporation: clinical experiences and perspective of use of electrochemotherapy. Future Oncol 2014;10(5):877-90. Crossref

25. Gangi A, Kastler B, Klinkert A, Dietemann JL. Injection of alcohol into bone metastases under CT guidance. J Comput Assist Tomogr 1994;18(6):932-5. Crossref

26. Groenemeyer DHW, Schirp S, Gevargez A. Image guided percutaneous thermal ablation of bone tumors. Acad Radiol 2002;9(4):467-77. Crossref

27. Callstrom MR, Charboneau JW, Goetz MP, Rubin J, Atwell TD, Farrell MA, Welch TJ, Maus TP. Image guided ablation of painful metastatic bone tumors: a new and effective approach to a difficult problem. Skeletal Radiol 2006:35(1):1-15. Crossref

28. Goetz MP, Callstrom MR, Charboneau JW, Farrell MA, Maus TP, Welch TJ, Wong GY, Sloan JA, Novotny PJ, Petersen IA, Beres RA, Regge D, Capanna R, Saker MB, Grönemeyer $\mathrm{DH}$, Gevargez A, Ahrar K, Choti MA, de Baere TJ, Rubin J. Percutaneous image-guided radiofrequency ablation of painful metastases involving bone: a multicenter study. J Clin Oncol 2004;22(2):300-6. Crossref

29. Cotten A, Deprez X, Migaud H, Chabanne B, Duquesnoy B, Chastanet P. Malignant acetabular osteolyses: percutaneous injection of acrylic bone cement. Radiology 1995;197(1):30710. Crossref

30. Wood T, Racano A, Yeung H, Farrokhyar F, Ghert M, Deheshi B. Surgical Management of bone metastasis: Quality of evidence and systematic review. Ann Surg Oncol 2014;21(13):4081-9. Crossref 